\title{
OPTIMALISASI BANYUWANGI IN YOUR HAND MELALUI FITUR PENGINTEGRASIAN GPS DAN TAX REFUND GUNA MENINGKATKAN CUSTOMER SATISFACTION
}

\author{
Anak Agung Gde Satia Utama1, Puput Puji Rahayu², \\ Shandy Harianto ${ }^{3}$, dan Debby Ratna Daniel ${ }^{4}$ \\ Fakultas Ekonomi dan Bisnis, Universitas Airlangga, Surabaya
}

\begin{abstract}
\begin{tabular}{l|l} 
Abstrak & Banyuwangi In Your Hand merupakan sebuah aplikasi yang terhubung dengan fiber optik
\end{tabular} yang menghubungkan 280 kilometer di 28 titik Kabupaten Banyuwangi. Namun, peningkatan jumlah wisatawan tidak sebanding dengan peningkatan jumlah pengunduh sehingga perlu adanya evaluasi mengenai fitur dan program yang ada pada aplikasi tersebut. Penelitian ini mengkaji proses updating informasi lokasi wisata pada aplikasi Banyuwangi In Your Hand. Penelitian ini merupakan penelitian deskriptif kualitatif. Data penelitian dikumpulkan melalui studi literatur dan wawancara pada para wisatawan yang sedang berkunjung di Banyuwangi. Hasil penelitian ini adalah usulan ide pengintegrasian Global Positioning System (GPS) untuk meningkatkan kinerja updating informasi lokasi wisata pada aplikasi Banyuwangi In Your Hand. Selain itu, penambahan tax refund pada fitur transaksi juga diharapkan dapat meningkatkan nilai dari aplikasi Banyuwangi In Your Hand tersebut. Tujuan dari penerapan kedua sistem tersebut adalah untuk meningkatkan customer satisfaction.
\end{abstract}

Kata Kunci : $\quad$ Banyuwangi In Your Hand, GPS, tax refund, customer satisfaction

\begin{tabular}{l|l} 
Abstract & $\begin{array}{l}\text { Banyuwangi In Your Hand is an application connected with fiber optic that has been } \\
\text { connecting } 280 \text { kilometers in } 28 \text { districts in Banyuwangi Regency. However, the increasing } \\
\text { numbers of the tourist is not in line with the numbers of application download. Therefore, } \\
\text { the application needs to be evaluated in terms of the feature and program. This study } \\
\text { examines the process of information update related to the location of tourism objects in } \\
\text { Banyuwangi. This is a qualitative descriptive study. Data were collected from literature } \\
\text { study and interviews with the tourists visiting Banyuwangi. This study proposed the idea of } \\
\text { integrating GPS in Banyuwangi In Your Hand application to increase the performance of } \\
\text { information update about tourism spots in Banyuwangi. This study also proposed to add tax } \\
\text { refund application on the transaction feature in order to increase the value of the } \\
\text { Banyuwangi In Your Hand application. The aim of the addition of both systems in } \\
\text { Banyuwangi In Your Hand application was to increase customer satisfaction. }\end{array}$
\end{tabular}

Keywords : $\quad$ Banyuwangi In Your Hand, GPS, tax refund, customer satisfaction

Fakultas Ekonomi dan Bisnis

Universitas Airlangga

gde.agung@feb.unair.ac.id 


\section{Pendahuluan}

Sektor pariwisata di Banyuwangi menunjukkan angka pertumbuhan yang baik. Banyaknya destinasi wisata alam baik wisata bahari, pegunungan, serta wisata budaya yang sangat terorganisir dalam berbagai event yang diselenggarakan oleh Pemerintah Kabupaten Banyuwangi. Minat wisatawan meningkat untuk berlibur ke kota Banyuwangi terbukti dengan jumlah wisatawan baik domestik maupun asing selama 2 tahun terakhir mengalami pelonjakan yang significant. Berdasarkan informasi yang dilansir di Travel Kompas.com pada tahun 2016 jumlah kunjungan wisatawan domestik 3 juta, dan wisatawan asing 72 ribu. Jumlah ini melonjak menjadi 4,6 juta wisatawan domestik, dan 92 ribu wisatawan asing pada tahun 2017 dan informasi ini bersumber dari Radar Banyuwangi, JawaPos.com. Peningkatan jumlah wisatawan yang mengunjungi Banyuwangi dirangkum oleh penulis dalam Tabel 1 berikut ini

Tabel 1. Peningkatan Kunjungan Wisatawan di Banyuwangi

\begin{tabular}{llll}
\hline No. & Wisatawan & $\begin{array}{l}\text { Tahun } \\
2016\end{array}$ & 2017 \\
\hline 1. Domestik & 3.000 .000 & 4.600 .000 \\
2. Asing & 72.000 & 92.000 \\
Jumlah & 3.072 .000 & $4.692,000$ \\
\hline
\end{tabular}

Sumber: Radar Banyuwangi, Jawapos.com.

Jumlah wisatawan yang terus meningkat tersebut didukung oleh pemerintahan setempat dengan mengeluarkan aplikasi Banyuwangi In Your Hand yang dapat memudahkan para pelancong yang datang untuk mengakses tempat wisata serta fasilitas pendukung yang ada di Banyuwangi. Dalam berita yang dimuat dalam merdeka.com Bupati Banyuwangi Abdullah Azwar menyampaikan, “... dengan dilaunchingnya Banyuwangi In Your Hand, wisatawan tidak perlu bingung. Sebab semua peta destinasi wisata, terminal, bandara hingga tempat makan enak di Banyuwangi bisa mudah ditemukan". Aplikasi ini juga sudah terhubung dengan fiber optik yang menghubungkan 280 kilometer di 28 titik. Targetnya aplikasi ini akan dipasang di 145 desa sehingga bisa menghubungkan 1700 kilometer. Para pelancong yang akan berkunjung di
Banyuwangi dapat mengakses Banyuwangi In Your Hand cukup dengan download dan memasang aplikasi ini secara gratis di Google Play. Sementara itu, Mohammad Shodiq, General Manager PT Icon+ Regional Surabaya sebagai penyedia aplikasi, mengatakan, aplikasi ini akan dikoneksikan dengan aplikasi serupa yang ada di Eropa dan juga Australia. Aplikasi yang dimaksud adalah Europe In Your Hand dan Australia In Your Hand. Jadi masyarakat di Eropa dan Australia juga dapat mengakses wisata yang ada di Banyuwangi.

Akan tetapi, dengan berbagai sistem dalam aplikasi yang diluncurkan oleh pemerintah Banyuwangi tersebut, efek pada peningkatan kunjungan dari wiasatawan dirasa kurang nampak. Hal tersebut dikarenakan, Banyuwangi In Your Hand hanya menyajikan informasi mengenai destinasi wisata yang ada dan informasi tersebut terbatas. Hal ini berdasarkan observasi penulis pada hari Selasa, 8 Mei 2018 pukul 21.05 WIB. Ketika penulis mencoba untuk mencari wisata alam air terjun Telunjuk Raung, data tidak menemukan lokasi wisata tersebut, padahal radius yang diatur untuk menjangkau lokasi wisata air terjun Telunjuk Raung telah dimaksimalkan sejauh $20 \mathrm{~km}$. Sementara, di instagram dan google, informasi wisata air terjun Telunjuk Raung telah tersedia.

Melihat jumlah unduhan aplikasi Banyuwangi In Your Hand di Google Play Store, dapat dikatakan menggunakan Banyuwangi In Your Hand dirasa kurang efisien dalam mengatasi permasalahan bagi para pelancong yang ingin datang ke Banyuwangi. Jika dibandingkan dengan jumlah unduhan atas aplikasi sejenis, Banyuwangi In Your Hand sangat terpaut jauh. Selain itu, informasi yang disajikan oleh Banyuwangi In Your Hand sangat terbatas, karena banyak bermunculan destinasi wisata baru yang belum tercapture. Padahal beberapa tempat wisata tersebut dapat menambah daftar referensi dalam melakukan liburan bagi wisatawan. Fitur transaksi pembookingan hotel juga tidak tersedia di aplikasi Banyuwangi In Your Hand. Aplikasi Banyuwangi In Your Hand tidak menyediakan layanan transaksi bagi para penggunanya, dan hanya menyediakan informasi lokasi, website, dan kontak yang dapat dihubungi baik telepon maupun email. 
Para wisatawan akan lebih merasa terbantu jika terdapat fitur transaksi pada Banyuwangi In Your Hand, karena pada dasarnya para pelancong menginginkan tersedianya proses pemesanan tiket perjalanan maupun tiket masuk ke destinasi wisata yang di inginkan. Fitur tersebut dirasa perlu dimasukkan dalam aplikasi keluaran pemerintah tersebut mengingat peningkatan jumlah wisatawan yang datang berbanding lurus dengan jumlah pemesanan hotel yang ada di Banyuwangi. Seperti informasi yang dilansir pada TribunBali.Com pada akhir tahun 2016 hotel-hotel berbintang di Banyuwangi sold out diserbu wisatawan. Apabila transaksi juga dilakukan pada kuliner terdaftar di aplikasi Banyuwangi In Your Hand, maka para wisatawan lebih dipermudah dalam melakukan transaksi, dan tidak menutup kemungkinan akan meningkatkan perekonomian bagi masyarakat Banyuwangi.

Menilik dari berbagai permasalahan yang ada, kami mengusulkan suatu sistem guna menyempurnakan aplikasi Banyuwangi In Your Hand dengan beberapa fitur yang akan menambah nilai dari aplikasi tersebut. Pada sistem yang akan kami usulkan, akan mengintegrasikan GPS pada radius yang mencakupi seluruh wilayah Banyuwangi untuk mengcapture beberapa destinasi wisata terbaru yang ada di Banyuwangi. Fitur transaksi merupakan salah satu sistem yang kami usulkan pada Banyuwangi In Your Hand untuk mempermudah para wisatawan baik domestik maupun mancanegara. Perlu adanya pembeda antara aplikasi Banyuwangi In Your Hand dengan beberapa aplikasi sejenis yang dikembangkan oleh pihak swasta, fitur tax refund akan menjadi kunci utama dalam penambahan nilai fungsi dari aplikasi Banyuwangi In Your Hand. Dengan beberapa fitur diatas, kami berharap akan meningkatkan customer satisfaction dari para pelancong yang dapat memberikan mereka kesan berbeda karena telah berwisata di Banyuwangi, sehingga diharapkan para wisatawan tersebut akan kembali mengunjungi Banyuwangi dikemudian hari.

Pertanyaan penelitian ini r adalah
bagaimanakah proses bisnis aplikasi
Banyuwangi In Your Hand setelah sistem
informasi wisata terbarui dan fitur transaksi tax refund ditambahkan? Tujuan penelitian ini adalah mengembangkan sistem GPS teritegrasi yang mencakup wilayah Kabupaten Banyuwangi dan fitur transaksi dengan sistem tax refund untuk mengatasi keterbatasan informasi dan pelayanan pada aplikasi Banyuwangi In Your Hand dan meningkatkan customer satisfaction.

Mobile aplikasi merupakan sebuah software yang dibuat dan diperuntukkan perangkat portable smartphone yang mengharuskan proses mendownload software mobile aplikasi di toko aplikasi agar dapat digunakan. Sedangkan untuk jenis toko aplikasi bervariasi seperti Apple App Store, Play Store, atau Blackberry App.

Menurut Wilkinson, 1991, sistem informasi akuntansi merupakan suatu rerangka pengkoordinasian sumber daya (data, materials, equipment, supplier, personal, dan funds) untuk mengkonversi input berupa data ekonomik menjadi keluaran berupa informasi keuangan yang digunakan untuk melaksanakan kegiatan suatu entitas dan menyediakan informasi akuntansi bagi pihakpihak yang berkepentingan. Bodnar \& Hopwood, 2010, mengatakan bahwa yang dimaksud dengan sistem informasi akuntansi merupakan suatu kumpulan dari berbagai macam sumber daya, seperti manusia dan juga peralatan yang dirancang untuk mengubah data keuangan dan juga data lainnya menjadi sebuah informasi yang berguna bagi user dan penggunanya.

Pengertian lainnya dari sebuah sistem informasi akuntansi diungkapkan oleh Jones dan Rama, 2006. Kedua tokoh tersebut mengatakan bahwa Sistem Informasi Akuntansi atau SIA merupakan sebuah subsistem dari Sitem Informasi Manajemen, dimana subsistem tersebut menyediakan informasi akuntansi dan keuangan, bersamaan dengan informasi lainnya dalam proses transaksi akuntansi yang rutin. Tokoh lainnya, yaitu Romney dan Steinbart, 2006, mengatakan bahwa yang dimaksud dengan sistem informasi akuntansi merupakan sebuah sistem yang mengumpulkan, mencatat, menyimpan, dan juga memproses data menjadi informasi yang berguna dalam membantu proses pengambilan keputusan. 
Dalam aplikasi Banyuwangi In Your Hand, Konsep tax refund (Pengembalian Pajak) sebagai salah satu penerapan indikator informasi sistem akuntansi daerah yang masih belum nyata terlihat kontribusianya. Tax refund ini adalah pengembalian dana atas barang kena pajak yang telah dibayar dengan uang. Hampir semua toko di luar terminal keberangkatan internasional mengenakan pajak dan biaya tambahan pada barang yang dijual. Untuk turis internasional, pajak ini dapat dikembalikan setelah mencapai jumlah tertentu. Kebijakan sistem pengembalian pajak (tax refund) bertujuan untuk mencegah pungutan pajak ganda antar negara. Terutama bagi masyarakat yang berbelanja di luar negeri. Pajak yang dimaksud adalah Pajak Pertambahan Nilai (PPN) yang semestinya tidak dikenakan bagi wisatawan asing yang berbelanja di suatu negara. Sebab, pungutan PPN semestinya ditujukan bagi wajib pajak (WP) di negara barang tersebut dikonsumsi.

Pengertian kepuasan adalah tingkat perasaan seseorang setelah membandingkan kinerja atau hasil yang dirasakan dibandingkan dengan harapannya (Susanto, 2000). Kotler dan Amstrong (1999), menyatakan bahwa kepuasan pelanggan (customer satisfaction) adalah suatu tingkatan dimana perkiraan kinerja produk atau jasa sesuai dengan harapan pembeli. Selanjutnya menurut Gerson (2001) menyatakan bahwa kepuasan pelanggan adalah perasaan yang dimiliki oleh pelanggan jika kebutuhannya secara nyata atau anggapan terpenuhi atau melebihi harapannya.

\section{Menurut American Society For Quality Control} (Lupiyoadi, 2011), kualitas adalah keseluruhan ciri-ciri dan karakteristikkarakteristik dari suatu produk atau jasa dalam hal kemampuan untuk memenuhi kebutuhan-kebutuhan yang telah ditentukan atau bersifat laten. Kepuasan jasa berpusat apada upaya pemenuhan kebutuhan dan keinginan pelanggan serta ketetapan penyampaiannya untuk mengimbangi harapan pelanggan.

Diperlukan adanya kiblat dalam melakukan riset terhadap suatu permasalahan, salah satunya adalah pada penelitian sejenis yang telah dilakukan sebelumnya. Seperti penelitian yang dilakukan oleh Tijana Radojevic, Nemanja Stanisic, dkk (2017) pada penelitian tersebut bertujuan untuk mengetahui keterkaitan antara traveling untuk bisnis dan kepuasan pelanggan dengan layanan hotel. Penelitian selanjutnya dilakukan oleh Jari Vanhanen, Timo O.A Lehtinen, dkk (2017). Penelitian tersebut membahas mengenai permasalahan kepuasan pelangaan yang dihadapi oleh proyek capstone. Survei dilakukan untuk mempelajari masalah, dan kepuasan pelanggan terkait dengan sebelas topik rekayasa perangkat lunak.

Sementara itu penelitian pada tax refud sebelumnya dilakukan oleh Sarah Octavia, dkk (2015), mengatakan bahwa, proses restitusi PPN di Indonesia sebagaimana diatur dalam Undang-Undang dan belum dikalukan secara online menyebabkan berbelit-belitnya prosedur sehubungan dengan restitusi PPN itu sendiri baik di internal ataupun eksternal DJP, banyaknya beban kerja yang ditanggung oleh Fiskus, dan lamanya pengembalian uang restitusi PPN kepada Wajib Pajak. Proses restitusi PPN di Indonesia yang diatur dalam Undang-Undang perlu dilakukan deregulasi atas peraturan tersebut agar proses restitusi PPN menjadi lebih cepat. Selain itu, restitusi PPN sebaiknya dilakukan secara online agar dapat memangkas jangka waktu dan prosedur itu sendiri.

\section{Metodologi}

Jenis penelitian ini merupakan penelitian kualitatif dengan pendekatan pengembangan proyek. Sumber data dalam penelitian ini bersumber dari data primer dan data sekunder. Data primer diperoleh dari wawancara dengan wisatawan atau pelancong yang sedang berwisata di Banyuwangi. Selain wawancara data primer, sumber data juga diperoleh melalui observasi aplikasi Banyuwangi In Your Hand. Sedangkan data sekunder diperoleh melalui data statistik kunjungan wisatawan di Kabupaten Banyuwangi serta literatur dan jurnal-jurnal yang relevan dengan penelitian. Penelitian dilakukan di tempat wisata yang ada di Banyuwangi pada tanggal 12 Mei sampai dengan 15 Mei 2018. Teknik pengumpulan data pada penelitian ini adalah: 
1. Identifikasi kebutuhan. Pada tahap ini dilakukan penggalian data dengan teknik wawancara dan observasi. Wawancara di Dinas Kebudayaan dan Pariwisata Kabupaten Banyuwangi dengan teknik semi wawancara. Wawancara juga dilakukan pada wisawatan baik domestik mauapun asing yang sedang berwisata di Gunung Ijen dan Pulau Merah. Sedangkan observasi dilakukan dengan cara mengamati sistem informasi Banyuwangi In Your Hand yang berjalan saat ini.

2. Analisis sistem. Tahap awal dilakukan dengan cara menganalisis sistem yang sudah ada menggunakan flow chart, dfd, dan erd.

\section{Hasil dan Pembahasan}

Keberadaan aplikasi Banyuwangi In Your Hand belum memberikan kesan puas kepada penggunanya, fakta ini dapat disimpulkan dengan melihat respon pengguna yang mengunduh aplikasi Banyuwangi In Your Hand melalui Play Store maupun App Store. Jumlah download sebanyak 100 dan komentar yang diposting berjumlah 4 komentar. Selain melihat respon pengguna melalui jumlah pengunduh, penulis juga melakukan wawancara kepada dua wisatawan lokal yang sudah hampir menjelajahi beberapa lokasi wisata di Banyuwangi dan satu wisatawan yang berasal dari luar Banyuwangi. Narasumber tersebut adalah Dani Hermawan 23 tahun warga Desa Kemiri, Kecamatan Singojuruh.

Hasil wawancara tersebut meyakinkan penulis untuk merancang sistem yang baru untuk aplikasi Banyuwangi In Your Hand. Sistem baru yang diusulkan oleh penulis adalah dengan menambahkan fitur transaksi dengan sistem tax refund pada aplikasi tersebut. Transaksi yang diusulkan akan melibatkan pihak bank sebagai penyedia jasa transfer serta sebagai pihak yang bertugas untuk mencairkan biaya tax refund. Untuk mengatasi permasalahan informasi lokasi wisata yang tidak lengkap maka penulis mengusulkan untuk menambahkan fitur GPS terintegrasi dalam aplikasi Banyuwangi In Your Hand. Fitur GPS terintegarsi tersebut memanfaatkan fitur tagar pada sosial media.
Berikut adalah rancangan aplikasi Banyuwangi In Your Hand dengan fitur transaksi tax refund dan fitur GPS terintegrasi.

Menurut Jogiyanto (2005) Diagram konteks adalah diagram yang terdiri dari suatu proses dan menggambarkan ruang lingkup suatu sistem. Diagram konteks merupakan level tertinggi dari DFD yang menggambarkan seluruh input ke sistem atau output dari sistem. Ia akan memberi gambaran tentang keseluruhan sistem.

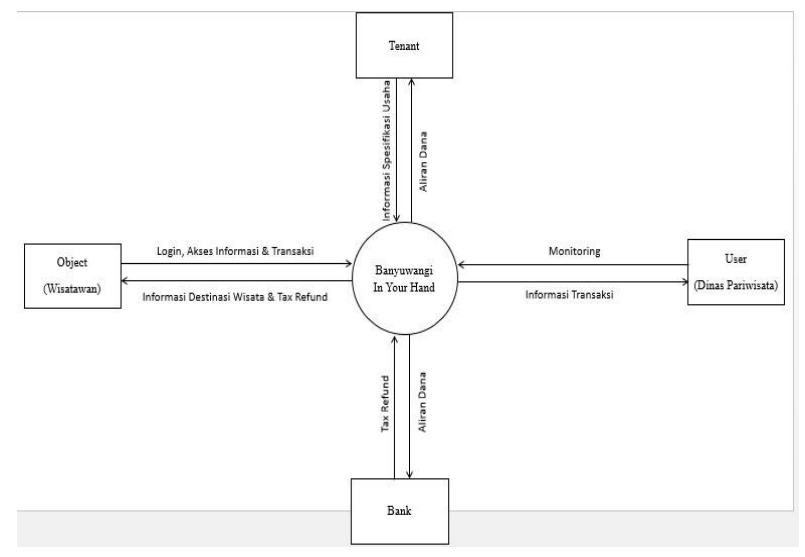

\section{Gambar 1. Usulan DFD Konteks Aplikasi Banyuwangi In Your Hand \\ Sumber: Hasil Penelitian}

Berdasarkan usulan tersebut pihak yang terlibat dalam sistem yang baru adalah Wisatawan, Tenant, Bank, dan Dinas Pariwisata. Fungsi setiap pihak dijelaskan berikut ini:

Tenant, pada aplikasi Banyuwangi In Your Hand adalah segala bentuk usaha yang berhubungan dengan bidang pariwisata, seperti hotel, restoran, dan agen travel. Tenant memiliki peran sebagai pihak penyedia layanan untuk wisatawan. Tenant akan memberikan informasi pelayanan yang ditawarkan baik dalam bentuk jasa maupun produk, informasi lokasi usaha, serta tarif yang disediakan bank. Fungsi bank dalam aplikasi Banyuwangi In Your Hand untuk menghimpun dana tenant yang diperoleh dari transfer wisatawan yang melakukan pemesanan layanan pada tenant. Serta sebagai pihak yang mencairkan dana tax refund untuk wisatawan baik secara tunai maupun tidak. User, adalah pengelola aplikasi yaitu Dinas Pariwisata Kabupaten Banyuwangi. User memiliki peran untuk mengawasi proses 
bisnis sistem dalam aplikasi Banyuwangi In Your Hand. Objek, dalam sistem adalah wisatawan baik lokal maupun mancanegara yang mengunjungi Kabupaten Banyuwangi. Wisatawan yang hendak melakukan transaksi atau sekedar melihat informasi mengenai wisata di Banyuwangi harus melakukan log in terlebih dahulu dengan mendaftarkan identitas mereka.

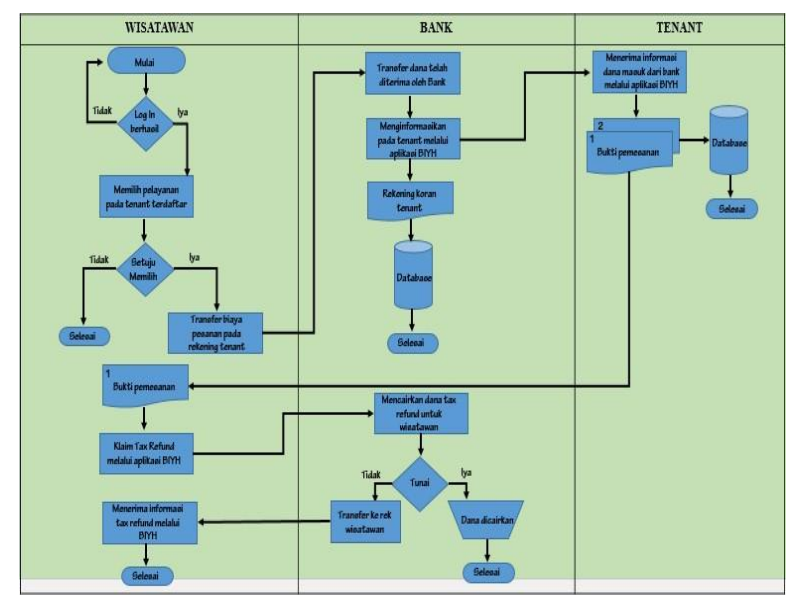

Gambar 2. Flowchart Sistem Transaksi Tax Refund

Sumber: Hasil Penelitian

Cara Kerja :

1. Wisatawan log in pada aplikasi Banyuwangi In Your Hand. Jika log in berhasil maka tenan dapat mengakses informasi dan memesan pelayanan pada tenant yang tersedia. Jika $\log$ in tidak berhasil maka ada kesalahan dalam melakukan $\log$ in.

2. Wisatawan memilih layanan yang tersedia. Layanan tersebut adalah membooking hotel, memesan kuliner pada restoran, dan memesan transportasi pada agen travel untuk berwisata di Banyuwangi. Jika wisatawan berminat dengan layanan yang tersedia maka wisatawan akan melakukan transfer ke rekening tenant untuk biaya + ppn yang secara otomatis tampil pada aplikasi Banyuwangi In Your Hand. Jika tidak berminat maka wisatawan tidak melakukan transfer ke rekening tenant.

3. Pihak bank menerima dana masuk dari tenant. Informasi dana masuk secara otomatis pada apllikasi Banyuwangi In Your Hand khusus untuk bank.
4. Bank memberikan informasi dana masuk kepada pihak tenant melalui aplikasi Banyuwangi In Your Hand.

5. Dana masuk tersebut lalu dicatat pada rekening koran tenant dan disimpan pada database di bank. Sebagai arsip apabila dibutuhkan.

6. Informasi dana masuk diterima oleh tenant melalui aplikasi Banyuwangi In Your Hand.

7. Tenant mencetak bukti pemesanan sebanyak 2 lembar. Lembar pertama untuk wisatawan dan lembar kedua digunakan sebagai arsip dan disimpan pada database.

8. Bukti pemesanan tersebut akan diterima wisatawan dan digunakan untuk mengklaim tax refund. Klaim tax refund dilakukan dengan aplikasi.

9. Bank menerima permintaan klaim tax refund melalui aplikasi Banyuwangi In Your Hand.

10. Pihak bank mengecek permintaan tax refund apakah tunai atau tidak. Jika tunai maka dicairkan pada saat itu, dan tentunya wisatawan sedang berada di Bank. Jika tidak maka pihak bank melakukan kliring dana tax refund ke rekening wisatawan.

11. Wisatawam telah memeperoleh dana tax refund atas transaksi pembelian dan pemesanan dilakukan pada aplikasi Banyuwangi In Your Hand.

Berikut ini merupakan flowchart untuk akses informasi lokasi wisata di Banyuwangi.

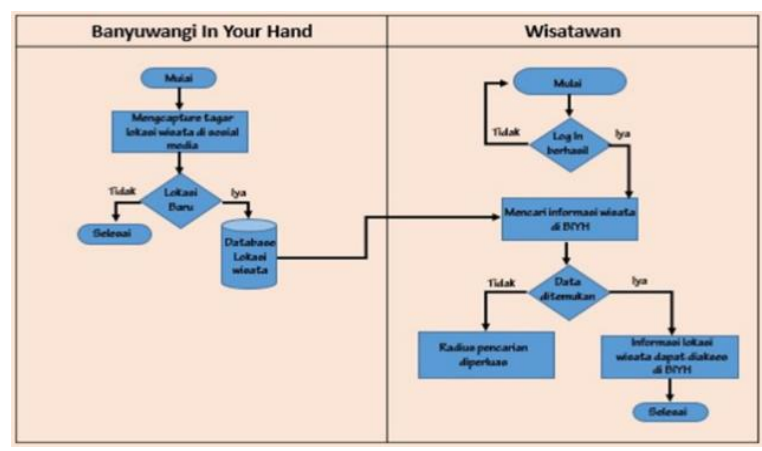

Gambar 3. Flowchart Sistem GPS untuk Akses Lokasi Wisata Sumber: Hasil Penelitian 
Cara Kerja :

1. Aplikasi Banyuwangi In Your Hand mengcapture lokasi wisata di Banyuwangi dengan memanfaatkan fitur tagar pada sosial media instagram, twitter, dan facebook.

2. Aplikasi menyaring informasi lokasi wisata dari tagar. Jika lokasi tersebut baru dan belum terdaftar pada database maka akan dicapture dan disimpan pada database. Jika lokasi wisata bukan lokasi yang baru maka tidak dicapture.

3. Wisatawan log in pada aplikasi Banyuwangi In Your Hand. Jika login berhasil maka dapat mengakses informasi lokasi wisata, jika login gagal maka harus menngecek kesalahan dan mengulang login.

4. Informasi yang didata dalam database dapat diakses oleh wisatawan. Dan wisatawan melakukan pencarian lokasi wisata di aplikasi Banyuwangi In Your Hand.

5. Jika lokasi ditemukan maka lokasi wisata yang diminta dapat diakses. Aplikasi akan menampilkan informasi seputar peta menuju lokasi, waktu dan jarak tempuh dari lokasi wisatawan, harga tiket masuk (bila ada), serta foto.

6. Jika lokasi tidak ditemukan, maka tombol radius yang tersedia pada aplikasi harus diperluas, agar informasi tempat wisata dapat diakses.

Berikut ini adalah diagram hubungan antar entitas (Entity Relationship Diagram) berikut ini:

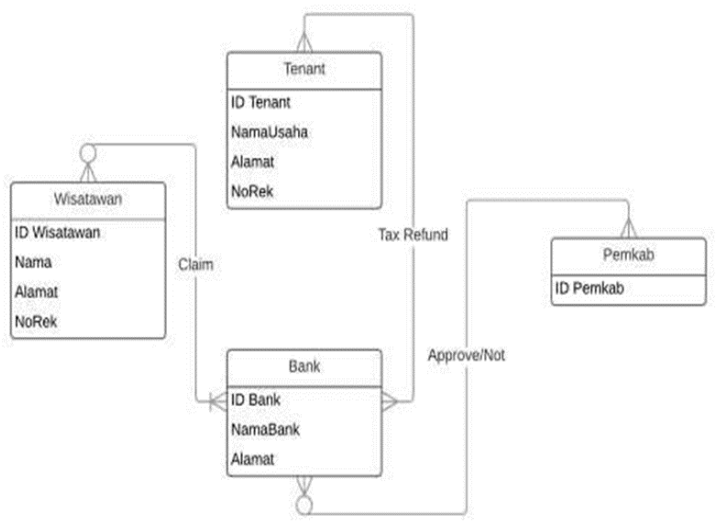

Gambar 4. Entity Relationship Diagram (Sistem Tax refund)

Sumber : Hasil Penelitian
Berikut adalah Entity Relationship Diagram untuk sistem pengintegrasian GPS dengan aplikasi Banyuwangi In Your Hand guna meningkatkan keakuratan dan perbaharuan informasi mengenai tempat wisata di Banyuwangi.

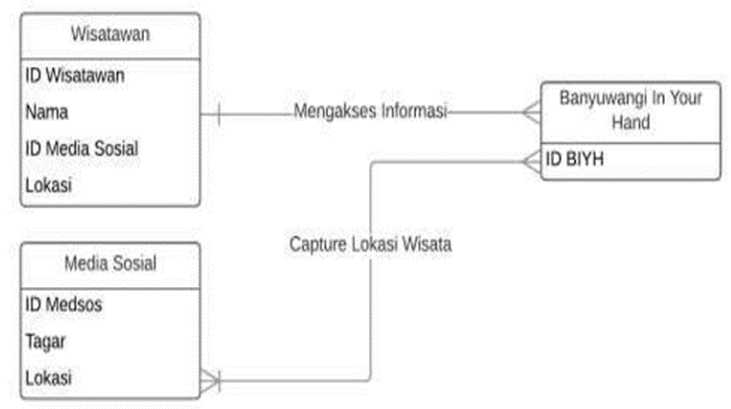

\section{Gambar 5. Entity Relationship Diagram (ERD) Sistem Pengintegrasian GPS Sumber : Hasil Penelitian}

Halaman ini merupakan halaman utama saat wisatawan membuka aplikasi Banyuwangi In Your Hand. Menampilkan informasi seputar lokasi wisata di Banyuwangi, seperti Pulau Merah, Wisata Osing, Kawah Ijen, dan Taman Sritanjung. Terdapat 5 menu utama dengan fungsi sebegai berikut :

1. Home

Menampilkan informasi seputar Banyuwangi

2. AR Scan

Mengambil kode QR disekitar lokasi pengguna untuk menunjukkan lokasi wisata mana yang terdekat

3. AR View

Mengambil gambar dilokasi pengguna untuk menunjukkan sedang dimana, dan lokasi wisata mana yang terdekat

4. Near Me Mengetahui lokasi wisata terdekat

5. Directory

Untuk mengakses informasi aktivitas, makanan, hotel dan vila, museum dan galeri, tempat ibadah, serta tentang Banyuwangi. 


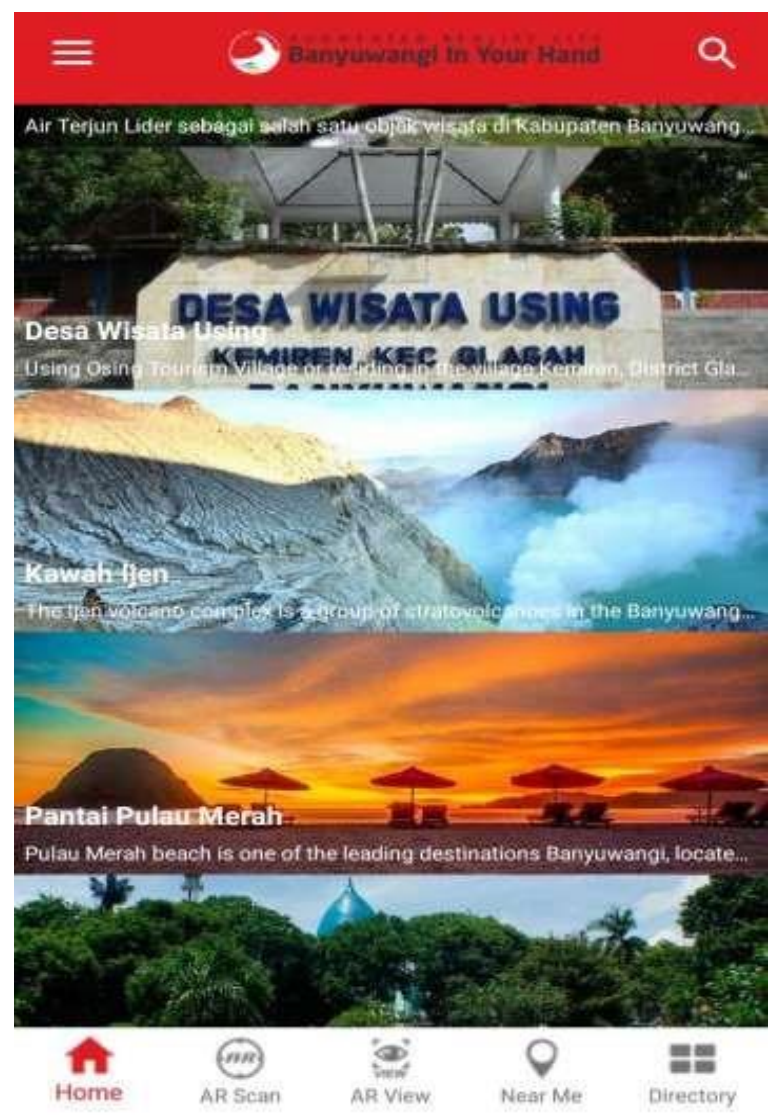

Gambar 6. Halaman Utama Aplikasi Banyuwangi In Your Hand Sumber: Google Play Store

Penerapan sistem transaksi dengan sistem tax refund pada aplikasi Banyuwangi In Your Hand akan membantu meningkatkan kepuasan pada pelanggan dalam hal ini adalah wisatawan. Dikarenakan aplikasi Banyuwangi In Your Hand tidak menyediakan fitur transaksi. Fitur tax refund merupakan sistem dari sistem yang diusulkan penulis, karena sejauh ini belum ada aplikasi sejenis yang menyediakan transaksi dengan tax refund. Selain itu sistem ini akan memberikan kemudahan bagi tenant karena tenant dapat dengan mudah memasarkan produk dan jasanya, serta mengecek pendapatan dan jumlah wisatawan yang menggunakan produk dan jasanya dalam satu aplikasi yaitu Banyuwangi In Your Hand yang secara langsung diawasi oleh Dinas Pariwisata Kabupaten Banyuwangi. Sistem GPS yang terintegrasi juga mendukung aplikasi Banyuwangi In Your Hand dapat meningkatkan kepuasan pelanggan, sebab dapat menyediakan informasi seluruh lokasi wisata yang terdapat di Banyuwangi.
Dari segi analisis biaya dan manfaat, sistem yang baru ini membutuhkan biaya yang cukup besar. Biaya yang dibutuhkan untuk perbaruan sistem ini adalah biaya programmer, biaya software, dan biaya pemeliharaan untuk aplikasi Banyuwangi In Your Hand. Tetapi sistem yang baru ini juga memiliki manfaat, terutama bagi tenant. Karena dengan adanya transaksi tax refund maka pendapatan tenant akan meningkat sebesar $10 \%$ lebih banyak. Wisatawan lebih senang jika diterapkan tax refund. Karena uang yang mereka belanjakan akan kembali sekian persen. Maka dengan adanya tax refund wisatawan akan lebih banyak mengeluarkan uang untuk belanja. Jika 1 wisawatan membelanjakan uangnya sebesar Rp 500.000 untuk satu kali belanja, dengan adanya tax refund wisatawan akan berbelanja minimal 2 kali lipat yaitu $\mathrm{Rp} 1.000 .000$. Sehingga pendapatan yang diperoleh tenan sudah pasti meningkat.

Pihak-pihak yang bekerjasama dan terlibat dalam usulan sistem yang baru adalah tenant, bank, object dalam hal ini adalah wisatawan, serta user yaitu Dinas Pariwisata Kabupaten Banyuwangi. Aplikasi Banyuwangi In Your Hand mengacu pada penggunaan teknologi jaringan internet, karena semua pihak terhubung secara digital.

Selain memiliki manfaat, sistem baru yang diusulkan untuk aplikasi Banyuwangi In Your Hand juga memiliki resiko yang akan ditimbulkan, antara lain: jaringan internet yang tidak stabil, sehingga memungkinkan transaksi tidak lancar, tidak semua tenant paham dan mau untuk menggunakan aplikasi Banyuwangi In Your Hand, serangan virus yang menyebabkan cybercrime pada aplikasi, biaya pemeliharaan sistem yang besar.

\section{Kesimpulan}

Penerapan fitur transaksi dengan sistem tax refund pada aplikasi Banyuwangi In Your Hand dapat membantu meningkatkan pendapatan pada tenant, dan kepuasan pada wisatawan. Penggunaan GPS terintegrasi dapat menampilkan informasi seluruh lokasi wisata secara lengkap pada aplikasi Banyuwangi In Your Hand. Perbaruan sistem aplikasi Banyuwangi In Your Hand dengan 
menambahkan fitur transaksi menggunakan tax refund serta fitur GPS terintegrasi, wisatawan dapat dengan mudah mendapatkan pelayanan dan informasi dalam satu aplikasi. Dalam proses penggunaan sistem yang baru pihak wisatawan dan tenant dapat bersamasama merasakan keuntungan, sehingga dengan sistem yang baru aplikasi Banyuwangi In Your Hand dapat meningkatkan kepuasan pelanggan.

\section{Saran}

Keterbatasan dalam penelitian ini adalah belum semua tempat atau titik wisata yang bisa ditangkap saat pemodelan sistem. Namun diharapkan model sistem yang diusulkan dapat menjadi panduan apabila sistem ini akan dijalankan di Kabupaten Banyuwangi. Diharapkan kedepannya melalui aplikasi Banyuwangi In Your Hand dapat meningkatkan jumlah wisatawan dan menambah pemasukan daerah Banyuwangi melalui sektor pariwisata.

\section{Ucapan Terima Kasih}

Terima kasih disampaikan kepada Tim Peneliti dari paper ini, diantaranya Puput, Shandi, Ibu Debby. Terima kasih pula kepada Asisten sebagai Tim Editor redaksional yaitu Pending Puji dan Dian Pratama. Serta, terima kasih kepada Pemerintah Kabupaten Banyuwangi dan Universitas Airlangga (PSDKU di Banyuwangi). Kepada semua pihak yang tidak dapat kami sebutkan satu persatu. Terima kasih atas dukungan dan sumber data dan informasi yang diberikan sehingga artikel ini bisa selesai dan siap untuk dipublikasikan.

\section{Daftar Referensi}

Banyuwangi Dalam Angka. tt. Transportasi, Komunikasi, dan Pariwisata. https://banyuwangikab.go.id/new/asset/20 15/bda/BDA_2014_Per_BAB/Tra nsportasi_Komunikasi_dan_Pariwisata_Bany uwangi_Dalam_Angka_2014.pdf. Diakses pada 22 April 2018 pukul 13.00 WIB.

Bodnar, George H. and William S. Hopwood, 2010. Accounting Information System. 10 $0^{\text {th }}$ Edition. United State Of America: Pearson Education Inc
Gerson, R. F. 2004. Mengukur Kepuasan Pelanggan. Jakarta: PPM

Jogiyanto, H.M, “Analisa dan Desain Sistem Informasi: Pendekatan Terstruktur Teori dan Praktik Aplikasi Bisnis", 2nd ed, Yogyakarta , ANDI, 2005.

Kotler, Philip, 1999. Marketing Management: Analysis, Planning, Implementation and Control. 9th Edition, Prentice Hall College Inc.

Lupiyoadi, Rambat dan A. Hamdani., 2011. Manajemen Pemasaran Jasa Edisi. 2, Jakarta: Salemba Empat.

Octavia, Sarah \& Yuniadi Mayowan, dkk. 2015. Analisis Proses Restitusi Pajak Pertambahan Nilai (PPN) di Indonesia. Jurnal Perpajakan (JEJAK), Vol. 7, No. 1

Rama Dasaratha V/ Frederick L. Jones. 2008. Sistem Informasi Akuntansi. Buku 1. Jakarta: Salemba Empat, 4 - 6

Radojevic, Tijana \& Nemanja, et al. 2017. The Effect Of Traveling For Business On Customer Satisfaction With Hotel Services. Tourism Management, Vol. 67, $326-341$

Romney, Marshall B. dan Paul John Steinbart, 2006. Accounting Information System, Buku Dua, 9th edition, Yogyakarta : Andi

Susanto, Azhar, 2000. Sistem Informasi Manajemen Konsep dan Pengembangannya, Bandung : Lingga Jaya

Vanhanen, Jari \& Timo, et al. 2017. Software engineering problems and their relationship to perceived learning and customer satisfaction on a software capstone project. The Journal of Systems and Software, Vol. $137,50-66$

Wahyudi, Moch. 2014. Soal Tax refund Wisman, Indonesia Mesti Belajar dari Singapura. https://www.merdeka.com/uang/soal-taxrefund-wismanindonesia-mesti-belajar-darisingapura.html. Diakses pada 21 April 2018 pukul 15.43 WIB.

Yudistirani, Irma. 2016. Hotel-hotel Berbintang di Banyuwangi Sold Out Diserbu Wisatawan. http://bali.tribunnews.com/2016/12/26/h otel-hotel-berbintangdi-banyuwangi-soldout-diserbu-wisatawan?page=all. Diakses pada 8 Mei 2017 pukul 00.00 WIB 